\title{
From sulphur to perfume: spa and SPA at Monchique, Algarve
}

\section{Cristiana Bastos}

To cite this article: Cristiana Bastos (2011) From sulphur to perfume: spa and SPA at Monchique, Algarve, Anthropology \& Medicine, 18:1, 37-53, DOI: 10.1080/13648470.2010.525872

To link to this article: http://dx.doi.org/10.1080/13648470.2010.525872

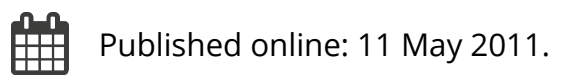

Submit your article to this journal ๘

LII Article views: 168

Q View related articles $\sqsubset$

Citing articles: 2 View citing articles 단 


\title{
From sulphur to perfume: spa and SPA at Monchique, Algarve
}

\author{
Cristiana Bastos* \\ Institute of Social Sciences, University of Lisbon, Portugal
}

(Received 1 July 2010; final version received 6 September 2010)

\begin{abstract}
In the thermal village of Monchique, Algarve, different streams of waterrelated knowledge and practices coexisted for centuries. Those waters were traditionally known as águas santas (holy waters) and believed to have redemptive healing powers. In the seventeenth century, the Catholic church took control of the place, refashioned the bathing rituals, developed infrastructures and provided assistance to the patients, granting free treatment to the poor. In the nineteenth century, the state replaced the church and imposed that treatments should be provided by professionals trained in the scientific principles of medical hydrology. Secular and scientific as they were, clinical logbooks still allowed for the account of patients that embodied miracle-like redemptive cures 'at the third bath'. People went to Monchique both for its magic and its medicine, bringing in the body ailments achieved in their lives of hard labour. They also went there for a socialising break while healing. From mendicants to rich landowners, coming mostly from the Algarve and neighbouring Alentejo, they crowded the place in summertime. In the twentieth century, as in other places in continental Europe, the spa evolved into a highly medicalised place that qualified for medical expenses reimbursements, which implied the eclipsing - at least from representation - of its leisure component. In the twenty-first century, a new trend of consumer-centred, market-based, postwater balneology with an emphasis on wellness and leisure reinvented the spa as place for lush and diversified consumption. This article argues that the seemingly contradictory systems (markets and medicine) coexist much in the same way that magic, religion and medicine coexisted in the old water sites. The new SPAs, rather than putting an end to the old spas, have enabled them to survive by reinventing thermal sites as places of attraction and leisure.
\end{abstract}

Keywords: water; healing; hydrotherapy; sulphur; spa; leisure; Algarve

\section{Redemption at the third bath}

Pedro António, a 35 year old rope-maker from the fishing village of Portimão, Algarve, could only move about with the help of a pair of canes. With impaired mobility, a record of syphilis, and enduring rheumatic pain for at least one year, Pedro might have foreseen living the rest of his days as a disabled person or, to use the vernacular of the time, as an entrevado - a word that resounds both of 'paralysed' and of 'in the darkness'. And yet something happened in a late spring day of 1874

\footnotetext{
*Email: c.bastos@ics.ul.pt
} 
that changed the gloomy prospect: he started walking on his own, reportedly, after a series of three baths.

In the following weeks and months of the same year, a similar experience occurred to a tailor named João Brigadeiro, aged 24, from Lagos, Algarve, who traded his two canes for a simple umbrella, again after the third bath; and equally to the labourer Manuel José Passarinho, 34, also from Lagos, who dropped his supporting cane...after the third bath; and to Agostinho José, 30, labourer in Odemira, Alentejo; to Maria Henriques, 32, a housewife from São Brás, Algarve; and to José da Silva, 30, a labourer from Monchique, Algarve. All of them started walking unaided 'after the third bath'.

What sort of bathing was this? Where and when did it take place? What sort of people, knowledge, symbols, material objects and gestures were involved? While the reference to a biblical resuscitation 'at the third day' may lead us to think of a holy shrine, perhaps a holy well, or a religious ritual involving water, the fact of the matter is that these reports of spectacular, quasi-miraculous healing were registered within a very secular genre: nineteenth-century medical logbooks.

Pedro, João, Manuel, Agostinho, Maria and José were treated with the waters of Caldas de Monchique in the year $1874 .{ }^{1}$ Each of them corresponds to one of the 749 line-entries that synthesise every patient's clinical history. The book was signed by the resident physician Francisco Lázaro Cortes and has survived until today. His comments on the redemptive 'third bath' appear as fait divers at the end of each line, just like 'got better', 'got cured', 'used águas férreas' (iron-rich waters from another spring in Monchique), or 'did not charge him for services provided at the spa' (referring to a doctor who stayed there), or 'came for the second time this year'. The redemptive 'third bath' was one more item in a log of personal and clinical data written about every person who received treatment.

Dr Francisco Lázaro Cortes and his logbook were novelties to Monchique. In 1872, the government had just established that the spa should have a resident physician to supervise the water treatments and register clinical data, so that science and professional clinical procedures replaced the current and perhaps inappropriate use of waters, solely based on traditional knowledge and religious good will.

There was a long history of healing acts and beliefs around the waters of Monchique. Like other springs and wells throughout Europe, those waters had been used for centuries as special, sacred, holy and redemptive of human suffering. ${ }^{2}$ There are local archaeological remains from the Roman period (about 2000 years). There is notice that at least one notorious king, John II (1455-1495), used its waters. ${ }^{3}$ However, also as in many other places, their users were mostly the anonymous peasants who left little material trace, but kept the beliefs and rituals alive throughout the ages. As with other things considered of the realm of magic and superstition, they were refashioned and re-styled by the Catholic church, which was hegemonic in Portugal since its beginning as a nation-state in the twelfth century. ${ }^{4}$ In that process of disciplining the bodies, the gestures, the words and the worldviews of the peasantry, the church provided names of saints to the sources and pools; built chapels and shrines next to them; adapted the rituals and prayers used by the waters; provided charitable assistance to the poor and the indigent.

Catholic control over Monchique materialised most expressively in the seventeenth century. Through the orders of the bishops of Faro, Algarve, some basic shelters were built in 1649: one for bathing, one for lodging (with three beds and a 
chimney for cooking) and one for the servants and the poor. They were refashioned in 1672 , but remained very basic. Major improvements came in 1691-1692, again via the orders of the bishops of Faro, who were granted the control of the place. The shelters were restored, an infirmary for the poor was added, a separate infirmary and dormitory for women was built in 1731. In 1752, 1780 and 1789 there were more improvements in the hospital, kitchen and baths, a mud pool was made, better accesses were opened, trees were planted and a physician from Lagos was brought to assist the poor (Acciaiuoli 1944, 169). In the early 1800s there were three pools for hydrotherapy, two of them named after saints - São João de Deus, with the capacity for 12 people, Santa Teresa, for up to six people, and, down the slope and large enough to hold up to 40 people, the pool of Pancada (literally, 'beating'), where the water fell from high up and hit the bodies like a strong shower (Tavares 1810; Soares 1835).

The church had to move out of the picture abruptly in 1834, when, in the aftermath of political upheavals, its estates all through the country, including the Algarve, were confiscated by the Portuguese government. For a few years, people used the waters of Monchique at their own risk, sometimes literally: with no supporting infrastructure, people would sometimes sleep under the trees, jeopardising the good effects of using the waters.

In 1840, the Algarve representative Mr Braklamy pleaded in the parliament for an urgent and rational intervention in Monchique. There was a wealth there, there seemed to be an exceptional healing power in its waters, one that had already cured thousands of paralytic and rheumatic patients in the past, and could eventually be used for respiratory diseases as well. This was too much to be left alone; it needed the professionalism of medicine and the universalism of science. There was also an underlying concern with the potential dangers of self-administration of mineral waters, a problem that in England had been compared to 'a sword in a madman's hands' by the advocates of the medicalisation of mineral waters (Harley 1990).

An increasingly secular state with a sympathy for medicine and science was to replace the church in the regulation of the access to water. There was a gap of inaction and neglect during the 1840s-1850s, a time when Charles Bonnet (1850) depicted the poor condition of Monchique and reported the indigence of his infrastructures, which were basically a building with two wings, separated by a dark and narrow corridor, having on one side the bath houses, chapel and kitchen, and little rooms for the bathers to rent, at the rate of 320 réis for 20 days. The government would soon intervene, sponsoring major renovations in 1862. By 1872 there was a regiment establishing the rules and the prices for taking the waters: 50 reis for a bath in the tub or in the small pool of Santa Teresa, 20 reis for a bath at the large Pancada pool, and 100 reis for a hygiene bath; those who had a certificate of poverty did not pay for the services. The improvements accounted for better ways of access, new infirmaries, and a permanent professional staff, which included two nurses of each sex, a clerk, laundry washers and janitors, and a resident physician, Francisco Lázaro Cortes, who supervised the treatments and the clinical record keeping.

In a curious way, amidst the standard banality of records about age, sex, birth, name, residence, profession, constitution, clinical background, previous conditions, prescriptions, results, Dr Cortes leaves a testimony about the persistence of a redemptive quality in the encounters of the suffering people and the reputedly holy waters. Some of the patients just dropped their canes and started walking ...at the third bath. 


\section{A close look at the customers}

Although there is no way to directly access the experience of those who walked after the third bath, it is possible to know a few things about them through the entries in the 1874 logbook - for instance, that all those six people were recent sufferers from the ailments or impairments that brought them to Monchique. Pedro Antonio's reumatismo articular (a broad definition for joint diseases) had been affecting him for a year, and was attributed to arrefecimento, or chilling, although syphilis is also listed in the column referring to pre-existing diseases. He arrived on 31 May and was prescribed a treatment of nine baths and 15 glasses of water. João, the 24-old tailor from Lagos, had been paralysed on his left side for about 4 months, his illness attributed to apoplexia cerebral, most likely what would be today referred as a stroke. He arrived on 4 June and was prescribed 15 baths and 22 glasses of water. Not only could he walk with the support of a simple umbrella after the third bath, but he left the place 'without the slightest sign of his disease'. Manuel, who walked in on a cane and dropped it after the third bath, suffered from reumatismo articular for the past nine months; in the past he had had malaria (febres palustres). He arrived on 14 June and was prescribed 15 baths and 15 glasses of water. Agostinho, the only one of this list of third-day-redemptions who was referred as 'poor' and as 'single', was a 30 year-old labourer from Odemira who suffered from generalized joint rheumatism (reumatismo articular generalizado) for the previous four months; like Manuel, his condition was attributed to 'chilling' (arrefecimento) and was prescribed 12 baths and 18 glasses of water after his arrival on 11 July. Maria, the 32-old housewife from São Brás, had suffered from sciatica over the period of a month with no apparent cause. She arrived on 31 July and was prescribed six baths, six showers and ten glasses of water. José, a local labourer who arrived towards the end of the season, on 16 September, had suffered for a month of what seemed an acute case of general joint rheumatism, probably related to his malarial condition (febres palustres). He was prescribed nine baths and 13 glasses of water.

Like Pedro, Maria, João, Manuel, Agostinho, and José, hundreds of men and women flocked to the waters of Monchique every year. Attendance was mostly seasonal, formally from May to September, but in fact starting in March-April and lasting to October-November (Figures 1 and 2). People came with rheumatic disorders, paraplegic conditions, impaired mobility, pain and discomfort. They came

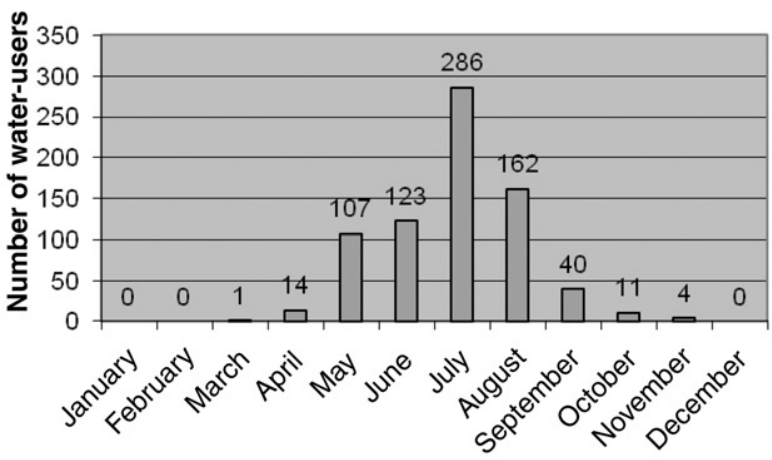

Figure 1. Monchique attendance, 1874: monthly frequency. 


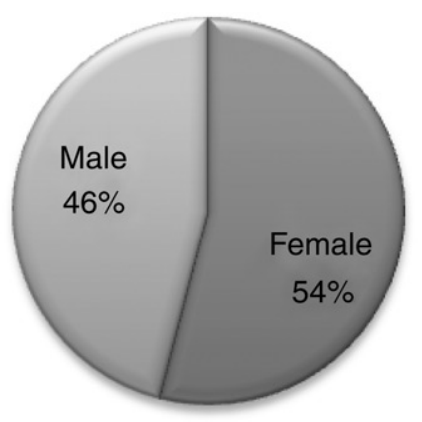

Figure 2. Monchique attendance, 1874: distribution by gender (346 men and boys; 402 women and girls).

from varied social backgrounds, with assorted ailments, and a common goal: to improve their condition via the use of the reputedly healing waters.

\section{Monchique in a wider context}

Bathing for wellness has been with humankind in many places and periods; sacred water holes exist around the world and major bathing cultures and architectures were developed at least under the Roman, Russian and Ottoman empires. The remnants of Roman water pipes, pools and extravagant bathhouses exist in sites that became spa-towns in later periods, as happened in Bath - the 'English Spa', a reference to the original 'Spa', a Belgian water site with a long tradition of curing and socialising. Bath catered not only to the illnesses but to the social needs of the eighteenth-century English gentry. Jane Austen provides a lively depiction of how families got together at Bath with the excuse of treating family members for gout, or simply without any medical excuse. Water drinking in the pump room punctuated a day filled with the activities of socialising, chatting, making friends, dressing up, parading, dining, dancing, establishing marriage alliances, developing the skills of conversation (Austen 1818; Hurley 2006).

That atmosphere was to decline in the following centuries, while, on the continent, spas flourished for a combination of reasons. Douglas Mackaman (1998) shows how the history of the French bourgeoisie and that of the modern spa are closely intertwined; vacationing according to the medicalised rhythms of the spa, but also to the sounds of ballroom dancing and casino gambling, was as much a constitutional part of the emerging class as their role in the production system. After a short period when the old spas were devalued for their associations with an aristocracy that had lost its high position in the French social structure, the reputation of the mineral water towns soon recuperated due both to the social needs of the emerging classes and to the developments of spa medicine. George Weisz (2001) argues that the development of medical hydrology and its institutionalisation as a respectful branch of medicine, its presence in medical curricula, and the lobbying power of its specialists, were crucial to maintain the centrality of water cures in France and achieve the one element that enabled, there and elsewhere, the longer 
survival of the old spa economy: the social security reimbursement of medically prescribed water cures.

Although a large number of French spas remained as austere in the nineteenth century as they had been in the renaissance (Brockliss 1990), the sophisticated architecture, landscaping and cultural activities developed in some of them provided a model for the development of some Portuguese termas, which aimed to attract the leisure-seeking classes, either from the still-existing local aristocracy or the emerging bourgeoisie. Vidago, Luso, Curia, Cucos, Caldas da Felgueira and others looked up to their French counterparts and tried to attract the fancy customers both on the basis of the therapeutic quality of the waters and the quality of leisure time one could spend there. Among the customers, some were habitués of the French, Italian and German spas, while others were new to the spa-culture. Old money and new money gathered in the palaces, grand hotels and casinos that were built around the buvettes (pump rooms) and bath houses of Luso, Vidago, Curia and other glamorous water springs. A liver condition, a troubled stomach, a rheumatic disorder, gout, pain, asthma, gynaecological ailments, neurasthenia, spleen, or recovery from the physical burdens of being in the colonies and other sites of 'tropical decay', 5 all were good motives for a period at the spa, where one could also bring along the family and socialise with those with similar motivations, tastes and social background. Spas became fashionable and desired experiences. In Ramalho Ortigão's (1875) account of spas \& baths in Portugal, a suggestive illustration depicts a teenager indulging in self-pity for being left alone in the city while all her friends had gone to the waters.

Having a genuinely good time by the waters was not incompatible with being there for a healing purpose, as Ferreira (1995) and Quintela $(1999,2003)$ argued for later periods of intense medicalisation of the Portuguese spas, and Cátedra (2009) and Speier (2010) further argued for their Spanish and Czech counterparts. Going for a cure at a traditional spa, even if highly medicalised, was a way of taking a break from daily routines, be they the drudgeries of labour, the stresses of ownership, or the boredom of sheltered lives. To meet, mingle and play with the peers was at least as important to the spa-goers as treating the gout or sciatica that brought them there - or the effects of working a life at a mine in Asturias, as in the spa of Ledesma (Cátedra 2009). People have invented creative ways of combining leisure and treatment at the spa, from claiming enjoyment at the quasi-torture of some of the Forges treatments in the nineteenth century (Mackaman 1998) to gastronomic hedonism; as witnessed in the 1990s in some Portuguese spas by the author, and confirmed in the ethnography of S. Pedro do Sul (Quintela 1999), three and four-course meals with plenty of wine were more likely to be found than light food and water. Customers and restaurant managers alike argued that plenty of food and wine were a deserved compensation for the harshness endured at the water treatments. $^{6}$

While some spas developed appropriate infrastructures for the needs of those who were more eager of entertainment than of treatments, others kept a more austere layout and a focus on their healing mission. Monchique in the late nineteenth century was somehow in between the two types. There were some improvements in the buildings that included a small 'casino', or a room to play cards and snooker, and there were pleasant views and airs to be enjoyed by the fashionable crowds seeking for status-promoting holidays at the spa. But Monchique, the "narrow valley', with 'difficult accesses' (Bonnet 1850), distant from the trains - the railway 
did not reach the Algarve until 1899 - was also quite out of the way for the trendy urbanites. The clientele was mostly from the region, predominantly rural, reflecting the social structure in the countryside at the time.

\section{Labour, class, pain and leisure in the south}

In 1874, the clients of Monchique came mostly from the neighbouring Algarve villages and towns, from the nearby coast, and from the Alentejo. A good number came from Faro and Loule, a few from the Eastern Algarve and one or two from Spanish Andalusia (Figure 3, Tables 1 and 2).

Among them, there were a few landowners, military officers and professionals that might use their time at the waters to build alliances and accomplish businesses, just like Austen's characters in Bath. There was a recreation room for playing cards and snooker (Ortigão 1875) and there were many outdoor locations to interact and socialise: by the water sources, under the trees of the valley or by the huge granite blocks that abound in the site. In the busier months, dozens of people gathered in Monchique at once, and there must have been a variety of forms of socialising. As in Vichy at the time (Mackaman 1998), this was not incompatible with the fact that some people suffered severe impairments, as it is reminded by the surviving wooden wheelchairs and litters kept in a small local museum at the spa.

Data from the logbooks indicate that the vast majority of those who went there had rheumatic diseases and other ailments of the bones and joints $(63 \%$ to $73 \%$, if sciatica and related disorders are included) and, to a lesser degree, skin, stomach and menstrual-related problems. Rich and poor, they had the chronic and acute versions of the omnipresent rheumatism.

Some of the clients appear as more pampered than others. Some women have a 'D.' before their name, for Dona; although it does not necessarily mean an aristocratic belonging, as would most likely be the case of a 'D.', for Dom, before a man's name, ${ }^{7}$ Dona is a sign of distinction and deference, a marker of social status that sets them apart from common people and labourers. That was the case with the four ladies who arrived together on 13 May: D. Maria da Gloria, D. Anna Nunes d'Almeida, D. Maria Purificação Almeida, and D. Cecília Adelaide d'Almeida. They were all registered as single and as domésticas, ${ }^{8}$ born in Pêra, Algarve, and residing there. They are likely to have been a group of land-owning close relatives from that small town who travelled together the few dozen miles between Pêra and Monchique. Only Anna, aged 34, had the ubiquitous reumatismo articular that affected most of the clients. She had had it for 4 months, the cause unknown. She was prescribed 13 baths and nine glasses of water. Maria da Gloria, aged 36, had 'herpes' for three years, and was prescribed seven general applications of water and 10 local applications, plus 13 glasses of water. Maria da Purificação, aged 24, had a lacrimal fistula for five years, probably caused by a 'lacrimal tumor'; she was prescribed nine general applications of water. Cecília Adelaide, 25, had dyspepsia for three years, attributed to 'lymphatism'. She was prescribed the ingestion of the iron-rich waters that came from a special spring in Monchique. All of them got better, except for Maria da Purificação, who neither improved nor worsened her eye condition. With no further data on this group, one can only speculate whether, were it not for Anna's rheumatism, the others would have ever made it to the spa. 
Table 1. Residence of Monchique attendants, 1874.

\begin{tabular}{lr}
\hline Local: Monchique and surroundings & 88 \\
Algarve (5 km-25 km from Monchique) & 320 \\
Algarve (over $25 \mathrm{~km}$ from Monchique) & 220 \\
Alentejo & 92 \\
Spain & 7 \\
Others/unknown & 21 \\
\hline
\end{tabular}

Table 2. Occupation of Monchique attendants, 1874.

\begin{tabular}{lrr}
\hline 'Domestics'/'Housewives' (just the name) & 236 & $31.6 \%$ \\
'Domestics'/'Ladies' (D.) & 84 & $11.2 \%$ \\
Land owners & 122 & $16.3 \%$ \\
Land labourers & 75 & $10.0 \%$ \\
Crafts (weavers, tailors, charcoal-sellers, shoemakers, carpenters, & 62 & $8.3 \%$ \\
$\quad$ cork cutters, rope makers, etc) & 35 & $4.7 \%$ \\
Professions (public employees, physicians, nurses, business) & 15 & $2.0 \%$ \\
Militaries & 5 & $0.7 \%$ \\
Sailors & 5 & $0.7 \%$ \\
Clergy & 1 & $0.1 \%$ \\
Student & 23 & $3.1 \%$ \\
Servants & 11 & $1.4 \%$ \\
Beggars & 74 & $9.9 \%$ \\
Unspecified & & \\
\hline
\end{tabular}
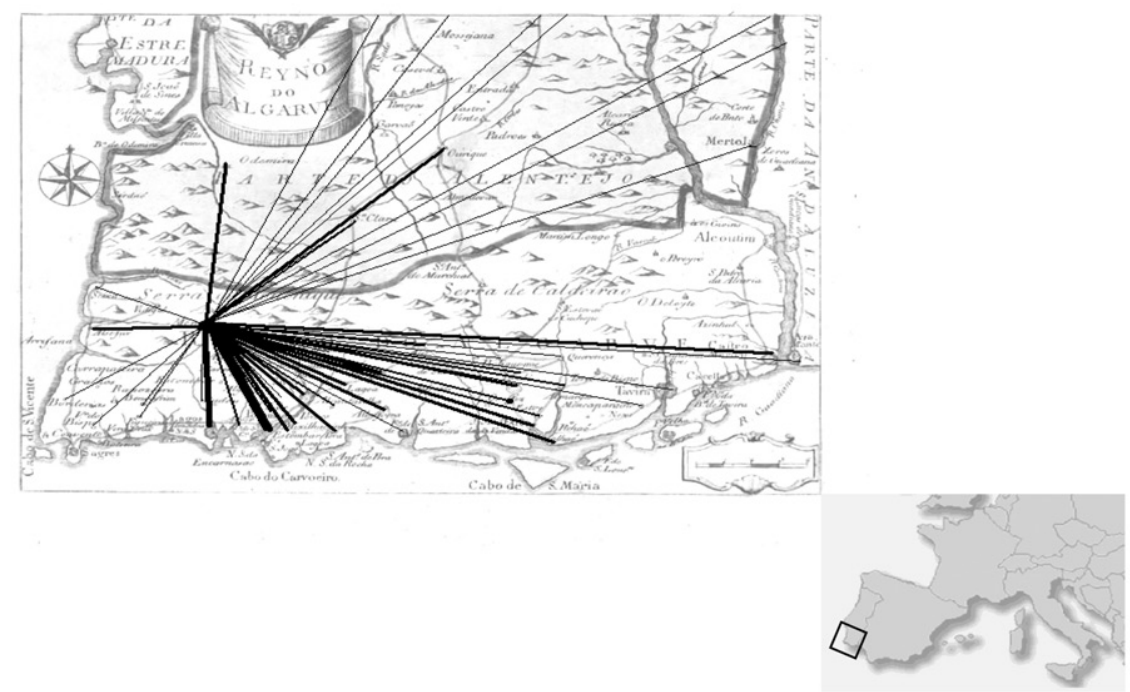

Figure 3. Geographic origin of Monchique attendants, 1874. 
It is also possible that Anna's rheumatism was a solid enough motive to set in motion a project of taking the waters in Monchique, and once this was established, the other three women had no shortage of smaller afflictions that could use some virtuous water.

Other people were not as pampered as those four women and came to the spa with a life of hard labour behind their ailments. Some of their afflictions were a direct effect of working in agriculture or in the manual crafts they had as carpenters, weavers, spinners, tailors, sailors, miners, cork-cutters, rope-makers. Many among them had difficulties with their limbs and joints, probably the result of the repetitive movements they made in the exercise of their crafts. Others had secondary effects of malaria, which was quite prevalent among agriculture workers in the southern areas of Europe at the time. Others suffered the consequences of inadequate nutrition, poor housing, excessive exposure to the elements - the sea, the sun, the heat, the cold, the rain and drought.

About one fifth (155 in 749) of those who received treatment in Monchique in 1874 were classified as poor. In a tradition that had been established by the church, and followed by the secular state, they did not pay for their treatments. Nothing indicates that they were subject to a lesser treatment or considered a nuisance to the other customers, as reported by Mackaman (1998) for some of the French spas; nor is there evidence that the poor were segregated along with those who had leprosy and syphilis, as it happened in some older Portuguese spas. ${ }^{9}$ But there were many other ways to materialise social stratification, such as with first-, second- and thirdclass bathing services. According to Sarzedas (1903), São João de Deus was the first-class bathing, and not a pool, but a service of individual bath tubs in private rooms, in a total of six; the smaller pool of Santa Teresa was the second classbathing; and the larger pool of Pancada served as third class. It was most likely here that the poor immersed their bodies.

Among the poor there were mendicants, servants and other low-income or unemployed labourers. Almost all of them suffered from reumatismo articular, or 'joint rheumatism', corresponding to the broad spectrum encompassed by 'arthritis' in today's currency. Sometimes, arthritis appeared as a separate category, either unqualified, depicted as 'generalized', or 'muscular'. A number of the poor patients were diagnosed with sciatica. A few had other less common conditions for the time: Antonio Moniz, a 48-year old labourer from the town of Loule, suffered from leprosy (elephantiasis dos gregos) on top of his arthritis. Manuel Maio, a 61-year old carpenter from Monchique, was paralysed on his right side (hemiplesia direita). José Gonçalves, a 15-year old boy from Lagos with no listed profession, had a 'painful ankylose' due to trauma. The waters brought him little relief and he left the spa using the same canes he came in with. The 3-year old child Antonio Simão, from the village of Algoz, Silves (Algarve), who was diagnosed as paraplegico, also remained unable to walk. Manuel Afonso, a labourer from Castro (Castro Verde, Alentejo), equally reported as paraplegico, kept moving around on his canes, and suffered from lower back pain. Ezequiel José, a labourer from Loule who suffered from the joints and probably the bones (osteite) as a consequence of malaria, improved his condition after the treatments. Thereza Emilia, a 25 year-old weaver from Monchique, had experienced a radical improvement in the previous year, not yet subject to the rigorous statistics of a logbook. She had arrived to the spa in 1873 as an entrevada (disabled) and had 
left the place walking on her own, and she was still doing so when in 1874 she arrived for another round of baths.

\section{The healing stench}

As mentioned above, Caldas de Monchique stood somewhere in between the fancier Termas do Vidago, Curia, Luso and others, with their lush promenades, palace hotels and exquisite buvettes, and the Catholic thermal hospital better epitomised by Caldas da Rainha (Figure 4). Located in the central-western region of the country, about $100 \mathrm{~km}$ north of Lisbon, Caldas da Rainha (literally, 'The Queen's Hot Springs') was reputedly home to the first thermal hospital in the world (Mangorrinha 2000). It was built in the fifteenth century by order of a sensitive Queen Leonor (1458-1525) who, reportedly, had witnessed how the poor peasants sought to alleviate their pains and improve their arthritic and rheumatic conditions by bathing in the warm sulphurous springs and muddy pools that existed in the place. Legendary as this is, it reports that people used those waters to heal their body ailments. One of them was leprosy: in a royal edict from 1223, the Portuguese King Sancho II allowed the interns of a leprosarium from the city of Santarém to journey to the place that was chosen later as the site of the Thermal Hospital. There developed the town of Caldas da Rainha; there, also, the smell of sulphur lingered in the air.

Like those of Caldas da Rainha, the waters of Caldas de Monchique were rich in sulphur, and thus smelly, albeit to a lesser degree. ${ }^{10}$ 'When entering the bath houses one immediately notices a sickening smell, mildly hepatic (hepatico) and suffocating', mentioned Dr Francisco Tavares in his 1810 general manual on Portuguese thermal waters. He noticed the white residue the water left in the pools and faucets; that the water was clear, but its taste sickening (enjoativo), 'with sparkles of iron'; and that

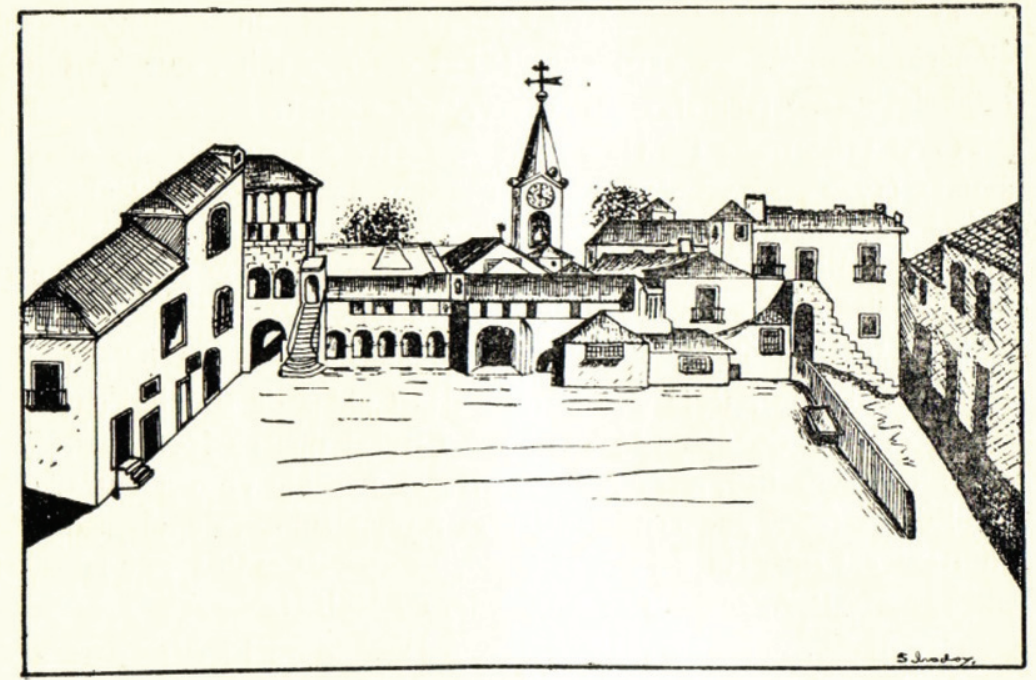

Figure 4. Caldas da Rainha, Portugal, sixteenth century. 


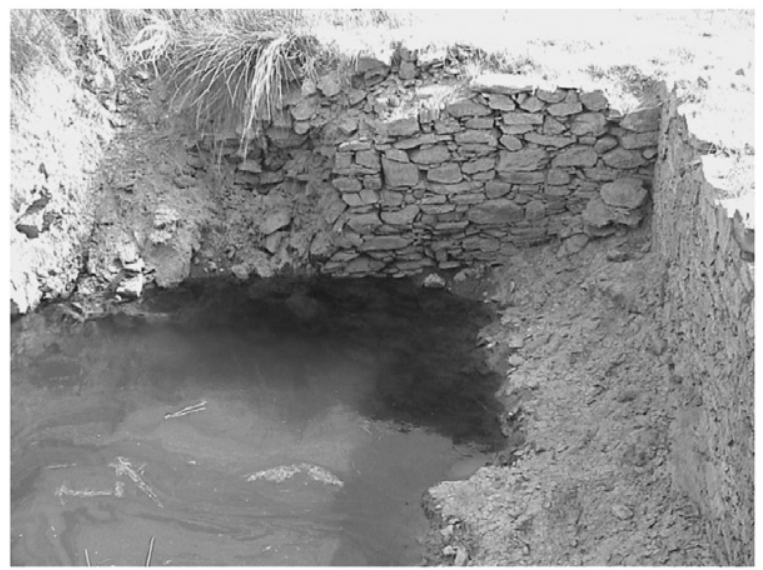

Figure 5. Rudimentary pool of sulphur water, out in the wild. (C) Leonor Areal.

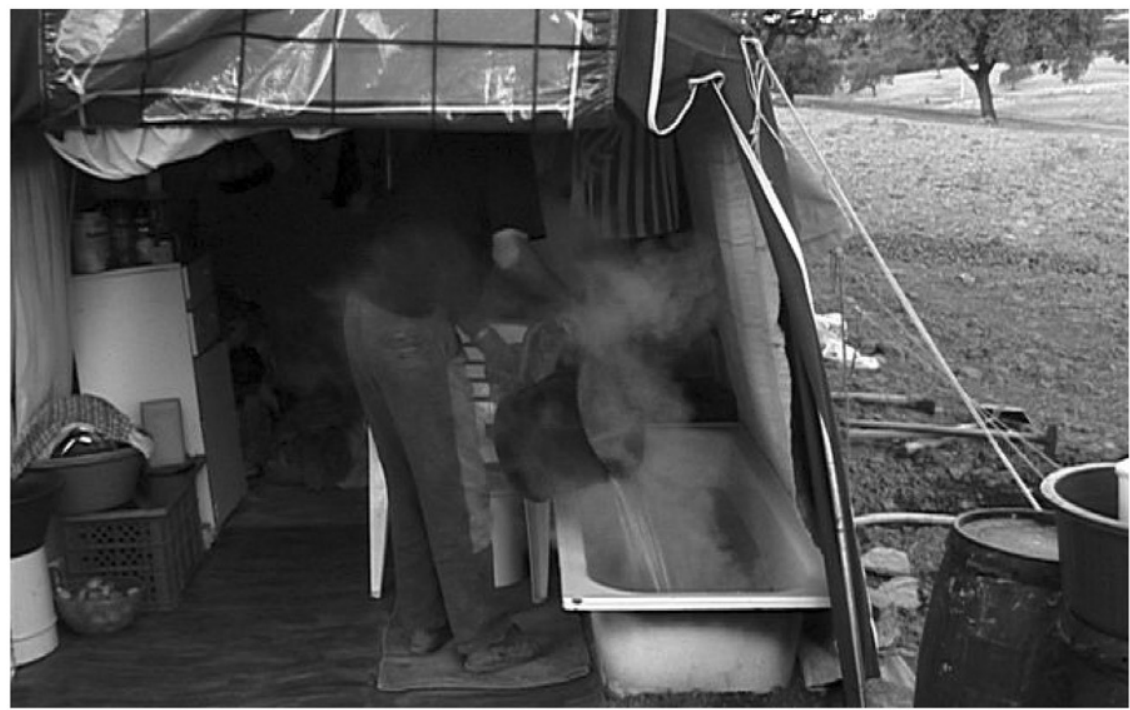

Figure 6. Self-catering, camping spa. (C) Leonor Areal.

after it cooled, the taste and smell would disappear, making the water totally suitable for drinking and cooking (Tavares 1810).

Sulphur, or the healing stench: its resemblance to hell, often reported by those who reflected upon its features, helped people out of the hell-like experience of bodily pain and impairment. The intense, 'sulphurous', rotten-egg smell of some waters is popularly associated with their healing powers. This was a belief widely shared across time and space, as Harley (1990) notes in his analysis of eighteenth- and nineteenth-century British manuals on mineral waters; in a 1803 treatise on the waters of Cheltenham, Dr. Thomas Jameson referred that 'if they had no bad taste nor smell, the patients would have no confidence in their virtues' (Harley 1990: 52). 
Whether appreciated or disliked, the smell persists in the air and remains in the skin, hair and clothes of the spa-goers; some claim that after a time of disliking it, they end up addictively craving for it. The smell also lingers around the ponds which, out in the wild, still attract people to take the waters at their own risk (Figures 5 and 6); people that camp next to smelly water ponds with no other infrastructure than the equipment they brought to heat the water and bathe; people that have their own views and interpretations for the reasons behind the powers of sulphur water - be it the 'energy achieved from the rocks' or its deeper 'connections to the center of the earth'. 11

In codified manuals, like the Aquilégio Medicinal, sulphur appears in association to Monchique's virtues: 'plenty of water, with sulphur, with great power (virtudes) for curing paralyses, stupor, all nerve conditions, and also stomach debilities, seizures, and other things that sulphur baths are good for' (Henriques 1726).

\section{From sulphur to perfume}

The growing medicalisation of European spas in the nineteenth century led to their institutionalisation in the twentieth - but only in some countries. The influence of medical hydrologists in making the field respectable and legitimate, and their treatments qualifying for reimbursement, well identified by George Weisz (2001) for France, had no counterpart in the British Isles. British spas declined while the French, German and also Portuguese ones flourished and their credibility enhanced - plus their use became routine to the many who believed in them, enjoyed them, and eventually used them for reimbursable medical holidays, reinforcing the 'medical' experience and talking more expressively of the painful side of it rather than of the pleasures associated with it.

Progressively, only the people on prescription went to the water springs. Excessive medicalisation of the Portuguese spas pushed the 'lure of the water' (Corbin 1988) towards the shores. Many places developed along the coastline with the new trend: Estoril and Cascais, close to Lisbon; the fishing shores of Ericeira (Jerónimo 2003) and Nazaré, further north, or Sesimbra, to the south; Figueira da Foz, next to Coimbra; the colder northern coast next to Oporto and the Galician coast of Vigo; and, at a later time, the golden cliffs and sunny beaches of the Algarve.

By the 1960s-1970s, Portuguese spas were no longer the first choice for fashionable and trendy consumers, nor were they the only treatment available for the sufferers of rheumatic diseases. Still, many people continued to visit them for treatment, and would not give up on having a good time while there (Ferreira 1995; Quintela 1999). They were mostly the ageing folks who preferred sharing the spa season (temporada) with their peers rather than going to the beach with younger family members, or who preferred submitting themselves to the time-consuming spa treatments rather than using pharmaceutical drugs, which they also dismissed either as useless or as having vicious side effects. They enjoyed meeting their partners in rheumatism and talking about their conditions, resembling an avant-la-lettre patient support group for people who often had no other choice for vacation and leisure than to take sick leave and receive medically prescribed treatments.

In sum, towards the end of the twentieth century, most Portuguese spas catered to an ageing and highly medicalised clientele. Termas seemed in frank decline, until a new trend began: the slow de-medicalisation of the spa and its reinvention as SPA. 
In general terms, the 'new spas', or SPAs, only partially resemble the older ones. Some emerged in the location of the old spas, benefiting from their reputation, existing travel routes and material resources that include exquisite architecture and prime landscape, not to mention what had once been central, the warm springs. In other cases, the new SPAs have appeared as subsections of old spas, as an extension of their products and services. Other times, SPAs have been built anew, whether or not around classified mineral water springs. The word 'SPA' is sometimes used as qualifier and added to a hotel's name, as the words 'palace' or 'grand' were in the past.

SPA invented itself as an acronym from the Roman-Latin etymology: 'Sanitas Per Acqua'. Not the town of Spa, in Belgium, a reminder of the sleepy old villes thermales that came alive every season with flocks of ailing curistes with numerous family members and protégées in tow, ready to socialise and make do with the rituals of assessing one's place in society.

The SPA is not about illness or disease: it presents itself as of health and well-being. The SPA is not sponsored by the state or by medical hydrology. Its attendance does not require a medical prescription, or the cultural capital of a family habitus; it requires money - or credit - and a lifestyle. The SPA is not about repeating an old formula supported by a branch of medicine and scrupulously followed by clients/patients. The SPA-goers like the diversification of SPA products and services; they like variety, innovation, choice; they like to feel free from the rules and regulations that structured attendance at the medicalised old spas. They like to be clients, not patients; they are consumers, not sick people. They carry credit cards and cash, not diseases. They want to purchase scented baths and exotic massages, not medical treatments. They want to decide whether to take a bath or ten, rather than follow the mandatory two or three weeks of daily treatments recommended by medical hydrology, sanctioned by commonsense, prescribed by resident clinicians and required by health insurance for reimbursement.

The new SPA does not really require the existence of thermal water, and sometimes there is no need of water other than to wash the body after coating it with extravagant products such as chocolate, grapes, coffee beans, lotions, oils, all amidst fancy massages, warm stones, crystal therapies, walks in the woods, meditation, mountain biking, gourmet food sampling and aromatherapy. In the new SPA, there is a clear preference for the flowery and pleasurable scents of perfumes, while the stench of sulphur, a reminder of the painful endurance of old style treatments, is if it ever is around - carefully kept away from the wellness rooms.

\section{Monchique, spa and SPA}

By the beginning of the twenty-first century, and after a history of different managements, decay and reconstructions, Caldas de Monchique reinvented itself as a modern spa-town, anticipating a trend that spread rapidly to most other locations as well. While, in the past, people visited the place for heavily ritualised programmes of thermal water-bathing, showering, inhaling, or drinking, all meant to heal and cure, today they mostly go there for self-designed programmes that may include water drinking, but also wine, coffee, tea, beer and liquor tasting; it may include bathing in mineral water, but at their pleasure and leisure, in pools or Jacuzzi-powered bathtubs, combined with immersions in fashionable SPA products 
ranging from chocolate to wine grapes and seeds, milky lotions and exotic balms. Water is no longer drunk at the buvette, still warm and smelly from the spring, and in the exact amount prescribed. Now, water may be consumed cold from odourless dispensers, at any time and any place for free, or purchased and carried home in bottles of Agua de Monchique or in its neatly designed new product, the 'chic' water.

Is that all Monchique has today, its miracles turned ancient myths? Has the SPA erased the medical spa, made it past history, bringing back the religious cult of nature and its elements in the form of a hedonist celebration of the senses backed by a cash-and-credit economy? Not really. Although less visible, having moved from the centre to the side of the place, the medical spa still exists and a significant number of patients attend it every year. In 2008, there were 621 people (230 men and 391 women) who went there for treatment, a number not too far from the 749 visits in 1874 .

Today, however, people come from further away; a large number reside in Lisbon, although their families may come from the Algarve and Alentejo. As in the past, they come in the summer, but peak attendance is in September, not, as in the past, July. They come mostly for muscular-skeletal (musculo-esqueléticas) disorders, still the general category for the same variety of disorders called reumatismo in the past. They come also to treat their throat and their respiratory disorders and, to a lesser degree, their stomach ailments. While the majority does not experience immediate results $(16.4 \%$ declare improvement, while $83.6 \%$ declare that they remained the same), a large majority improve their condition in the long run: $31 \%$ report 'mild improvement', $48.4 \%$ report 'improvement', and $15 \%$ report 'strong improvement'. 12

While no longer 'at the third bath', and no longer as in a miracle, people still claim that the waters of Monchique can heal them.

\section{Conclusion: has the SPA put an end to the medical spa?}

In summary, the SPA has not replaced or put an end to the old spa. Instead, the argument of this article is that the SPA has enabled the old spa to survive, by reinventing thermal sites as places of attraction, leisure, and consumption. In the older version, spas were mostly about healing, and the church was keen to administer the reputed miracles of their waters. In the nineteenth century, the trend of medicalisation attracted a growing number of clients who enjoyed their disciplined, medically-supervised vacations as well as the accompanying glamour. In the twentieth century, as spa medicalisation became stricter, leisure-seeking clients turned elsewhere, either to the beach, the mountains, radical sports, gambling, ecotravel, or other assorted products invented by the tourist industry. Towards the end of the twentieth century, spas were in serious decline and many people foresaw their total extinction. And yet, in the twenty-first century, spas have reinvented themselves as SPAs, introducing leisure as a product and flexible consumption as a mandate. But, contrary to some predictions, the new SPAs coexist well with the old spas. At least, this is the case in Monchique, which continues to cater to a number of visitors that, in the end, differs little from the seven hundred plus who sought its waters in the year 1874 . 


\section{Acknowledgements/Funding}

Research for this paper was funded by the projects Empires, centers and provinces: the circulation of medical knowledge (FCT-PTDC/HCT/72143/2006), and Das termas aos Spas: reconfigurações de uma prática terapêutica (FCT- POCTI/ANT/47274/2002). The author thanks Antonio Perestrelo de Matos and Maria Manuel Quintela, who were part of the research team that surveyed virtually all water springs in continental Portugal, and to Frederico Rivera and Jorge Rivera, who volunteered in the survey with enthusiasm. Further thanks go to Leonor Areal for the photographs, to Alexandra Baixinho for maps, to the Monchique Spa Director Tiago Martins Barata, who made access to sources an easy and enjoyable task, and to the many anonymous users of mineral waters that throughout the country shared with the team their views and perspectives. The author would also like to acknowledge the insightful, generous and useful comments and suggestions of the anonymous reviewers of this article.

Ethics committee requirements: research draws on data from the nineteenth century. No human subjects were involved in experiences. The person in Figure 6 consented in being photographed.

Conflict of interest: none

\section{Notes}

1. Caldas, like termas, stands for warm water springs, and 'Monchique' (reportedly from the Arabic names for 'sacred mountain') refers to the mountains where they are located, in the western Algarve, southern Portugal. Caldas de Monchique and the nearby town of the same name are about $20 \mathrm{~km}$ off the southern shore (Alvor, Lagos), $25 \mathrm{~km}$ off the western shore (Aljezur), and $10 \mathrm{~km}$ off the dividing line with the Alentejo province (County of Odemira). Those mountains result from a granite-sienite surfacing amidst a mostly schist and limestone geology. As in northern Portugal, the warm sulphur springs appear most often along with the granite. The data hereby presented come from the clinical logbook started in 1874, which is kept in good condition and belongs to the historical collection preserved at the Monchique estate.

2. For example, Logan (1981), Bord (2006, 2008); while literature on pre-historic medicine and ethnomedical systems of knowledge has focused primarily on the therapeutic use of plants and disregarded the role of water-based healing, the literature on ancient bathing has focused primarily on leisure, hygiene and social regulation (e.g. Jackson 1990), leaving thus unattended the area of pre/historic or ancient water cures.

3. Reputedly poisoned by his enemies, John sought treatment in the Monchique, but not even those waters were able to rescue him. Ill-fated King Sebastian (1554-1578) is also reported to have passed by Monchique on his way to the fatal battle of Alcacer Kibir (Morocco). Other mineral springs had more auspicious encounters with royalty: the waters of São Pedro do Sul treated Afonso Henriques' (1111-1185) war fractures; Caldas da Rainha, (Queen's spa) owed its hospital, its name and its existence to the grace of Queen Leonor (1458-1525); in Brazil, Caldas da Imperatriz (Empress' spa) mimicked that name while paying homage to the visit of the recently empowered empress Leopoldina (1797-1826), wife of the first monarch of Brazil, Emperor Pedro.

4. Dating back to 1143 , Portuguese independence was, since its beginning, closely associated with Christianity: northern crusade knights got involved in local Iberian disputes and in the 'reconquest' of the southern lands from the Muslim rule. Rome supported the new Christian kingdom, which kept some degree of religious tolerance towards its Jewish and Muslims communities until the early sixteenth century, when non-Christians were expelled, slaughtered or converted by force.

5. Portuguese colonial officers were often prescribed spa treatments back home in order to recover their balance and health. There are several references to leaves of absence in Portuguese colonial records that included temporary spa treatments. To my knowledge, 
though, there were no attempts of turning the water springs located in the colonies into spas, as Eric T. Jennings (2006) so thoroughly describes for the French empire.

6. Fieldwork in the 2000s showed that the emergence of wellness SPAs helped to open a niche for lighter foods, timidly making room among the hedonistically heavy cuisine that pervades in most places.

7. This is valid for the Portuguese language, where the use of Dom is mostly reserved, although not exclusively, for aristocracy and high clergy, as opposed to Spanish, where Don is applied to a wide number of gentlemen.

8. Doméstica, literally 'from home', is most often translated as 'housewife', but it really does not mean that they were part of a husband-and-wife couple. The term was used to refer to the women who did not work outside the home, either poor or rich. Although vague, the classification stands in the way for a better understanding of the social stratification of the female population of water users.

9. Evidence was collected in the course of the project Das termas aos spas and is published on the site www.aguas.ics.ul.pt.

10. It is not the sulphur in itself that has the smell, but its dioxide, which resembles the unpleasant odour of rotten eggs. Some of the hot springs of the granitic lands of Northern Portugal, such as São Pedro do Sul, Caldas da Felgueira, Alcafache, etc, have a smell that is far more intense than that of Monchique, which can hardly be noticed today.

11. In the course of fieldwork in rural Portugal in 2003-2004, the research team found a number of people taking the waters in the most precarious conditions, in quasi-barracks or out in the wild, either self-catering or using very basic shelters where the water was supplied by ad hoc assistants who lived nearby or happened to own the shelter (Bastos 2004, 2006).

12. All data refer to the clinical report for the 2008 thermal season of Caldas de Monchique, signed by the clinical director Dr Estela Maria Quintino Avelar de Castro. The author is very grateful to Tiago Martins Barata and Claudia Vilela, from the spa management, for kindly providing the data.

\section{References}

Acciaiuoli, Luís de Meneses. 1944. Águas de Portugal: minerais e de mesa: história e bibliografia. Lisboa: Direcção Geral de Minas/Soc. Tipográfica, Vol. IV.

Austen, Jane. 1818. Northanger Abbey. London: John Murray.

Bastos, Cristiana. 2004. A cura pelas águas: estado da questão, tendências históricas e notas etnográficas. Paper delivered at the seminar A cura pelas águas em portugal: estudos antropológicos, históricos e patrimoniais, Termas do Luso, 17-18 July.

Bastos, Cristiana. 2006. Das Termas aos 'Spas': reconfigurações de uma prática terapêutica. http://www.aguas.ics.ul.pt/docs/dinamicas.pdf

Bonnet, Charles. 1850. Algarve (Portugal): description géographique et géologique de cette province. Lisbonne: Typ. de la Acad. Royale des Sciences.

Bord, Janet. 2006. Cures and curses: Ritual and cult at Holly Well. Loughborough: Heart of Albion Press.

Bord, Janet. 2008. Holy wells in Britain: A guide. Loughborough: Heart of Albion Press.

Brockliss, L.W. 1990. The development of the spa in seventeenth-century France. Medical History Supplement, no. 10: 23-47.

Cátedra Tomás, Maria. 2009. El agua que cura/Healing Waters. Revista de Dialectología y Tradiciones Populares LXIV, no. 1: 177-210.

Corbin, Alain. 1988. Le territoire du vide: L'Occident et le désir du rivage, 1750-1840. Paris: Aubier.

Ferreira, Claudino. 1995. Estilo de vida, práticas e representações sociais dos termalistas. O caso da Curia. Revista Crítica de Ciências Sociais 43: 93-122. 
Harley, David. 1990. A sword in a madman's hand: Professional opposition to popular consumption in the waters literature of Southern England and the Midlands, 15701870. Medical History, Supplement 10: 48-55.

Henriques, Francisco da Fonseca. 1726. Aquilégio Medicinal ..., Lisboa: Oficina da Música.

Hurley, Alison E. 2006. A conversation of their own: Watering-place correspondence among the bluestockings. Eighteenth-Century Studies 40, no. 1: 1-21.

Jackson, R. 1990. Waters and spas in the classical world. Medical History Supplement, no. 10: $1-13$.

Jennings, Eric T. 2006. Curing the colonizers: Hydrotherapy, climatology, and French colonial spas. Durham: Duke University Press.

Jerónimo, Rita. 2003. Banhistas e Banheiros: Reconfiguração Identitária na Praia da Ericeira. Etnográfica 7, no. 1: 159-69.

Logan, Patrick. 1981. The Holy wells of Ireland. Ireland: Colin Smythe.

Mackaman, Douglas Peter. 1998. Leisure settings: Bourgeois culture, medicine, and the spa in Modern France. Chicago: University of Chicago Press.

Mangorrinha, Jorge. 2000. O lugar das termas: património e desenvolvimento regional: as estâncias termais da Região Oeste. Lisboa: Livros Horizonte.

Ortigão, Ramalho. 1875. Banhos de caldas e águas mineraes. Porto: Magalhäes \& Moniz.

Quintela, Maria Manuel. 1999. Entre Curar e Folgar: etnografia das termas de S Pedro do Sul. Tese de Mestrado. Lisboa: ISCTE.

Quintela, Maria Manuel. 2003. Banhos que Curam: Práticas Termais em Portugal e no Brasil. Etnográfica 7, no. 1: 171-85.

Sarzedas, J.A.R. Tenreiro. 1903. Relatório sobre a inspecção médica às águas mineraes e suas estancias em 1902. Lisboa: Imprensa Nacional.

Soares, Alexandre Augusto de Oliveira. 1835. Considerações fysiologico-praticas sobre a medicina cutânea. Lisboa: Typ. da Academia Real das Sciencias.

Speier, Amy. 2011. Health tourism in a Czech spa. Anthropology and Medicine 18, no. 1: $55-66$.

Tavares, Francisco. 1810. Instrucções e cautelas practicas sobre a natureza, diferentes especies, virtudes em geral, e uso legitimo das águas mineraes, principalmente de Caldas. Coimbra: Real Impr. da Universidade.

Weisz, George. 2001. Spas, mineral waters and hydrological science in twentieth-century France. Isis 92, no. 3: 451-83. 